\title{
Smeltetabletter - fordeler og ulemper
}

Interessen for smeltetabletter har økt betraktelig de siste årene, og en rekke nye produkter er kommet på markedet. Smeltetabletter løser seg raskt i spyttet i munnen, uten tilførsel av ekstra væske, og danner en suspensjon som er lett å svelge. De er egnet for pasienter som har problemer med å ta vanlige tabletter, slik som barn, eldre og sengeliggende.

Se også kunnskapsprøve på www.tidsskriftet.no/quiz

Podkast på www.tidsskriftet.no

Ingunn Tho

ingunn.tho@uit.no

Institutt for farmasi

Universitetet i Tromsø

Smeltetablettene kom på markedet i 1980årene. De ble først og fremst utviklet for pasienter med problemer med eller vegring mot å svelge tabletter, som barn, eldre, sengeliggende pasienter og slagpasienter. I dag finnes et bredt spekter av legemidler i form av smeltetabletter, inkludert reseptfrie legemidler mot allergi og smerte. Formålet med denne artikkelen er å gi en oversikt over hvilke virkestoffer som finnes som smeltetabletter på det norske markedet, samt belyse fordeler og ulemper knyttet til doseringsformen.

Grunnlaget for artikkelen er litteratursøk i SciFinder og Medline. Det er gjort et skjønnsmessig utvalg av artikler ut fra forfatterens erfaring innen legemiddelteknologi og biofarmasi. Oversikten over hvilke legemidler som finnes som smeltetablett på det norske markedet er fremkommet gjennom søk i Felleskatalogen 2011 (1)

\section{Terminologi}

Ifølge norske legemiddelstandarder er «smeltetablett» en samlebetegnelse for preparater som løser seg raskt i munnen: «Smeltetabletter er frysetørrede preparater eller tabletter med hurtig frisetting av legemidlet. De er beregnet til å plasseres på tungen eller eventuelt å dispergeres, eller oppløses i vann før bruk» (2). Tablettene fremstilles ved hjelp av svært forskjellig teknologier: frysetørking, komprimering og ulike smelteteknologier. Preparatene vil ha forskjellige egenskaper avhengig av fremstillingsmetode, men fellesnevneren er at de løses raskt opp i munnen, som regel i løpet av få sekunder, uten ekstra tilførsel av drikke. Tablettene omdannes i munnen fra fast form til en flytende suspensjon, eller en geleliknende masse, som er lett å svelge. Ifølge den europeiske farmakopé skal en smeltetablett (orally disintegrating tablet, ODT) dispergeres på under tre minutter (3). Sublingvaltabletter faller inn under definisjonen av smeltetabletter. Tabell 1 gir en oversikt over virkestoffer som er tilgjengelige som smeltetabletter på det norske markedet (1).

\section{Problemer med å svelge tabletter}

Problemer med å svelge tabletter er et fenomen som forekommer i alle aldersgrupper. Ifølge en amerikansk studie er dette et problem hos ca. $35 \%$ av normalbefolkningen (4). Videre estimeres det at hele $65-75 \%$ av eldre på institusjon og rundt $55 \%$ av pasienter i langtidspleie har problemer med å svelge tabletter. Problemene er knyttet til tablettens størrelse, overflate, form og smak $(4,5)$.

Når det gjelder barn, er det først og fremst faren for at de skal sette tablettene fast $i$ halsen og få pustebesvær som begrenser bruken. Nyere forskning viser at størrelsen er avgjørende for hvorvidt barn kan svelge tabletter. Veldig små tabletter, såkalte minitabletter (2-3 mm i diameter) har vist seg å være akseptable for barn helt ned i førskolealder (6). Smeltetabletter i slik ministørrelse, spesielt beregnet på de yngste barna, er under utvikling (7).

\section{Fordeler}

Smeltetabletter kombinerer fordelene fra faste og flytende doseringsformer. De har god doseringsnøyaktighet, god stabilitet, enkel og billig fremstillingsmetode, små pakningsstørrelser og er lette å håndtere for pasienten, egenskaper som tradisjonelt sett er typisk for faste doseringsformer. Samtidig er de lette å svelge, og det er ingen fare for å sette dem fast $i$ halsen, noe som betraktes som typiske fordeler ved flytende doseringsformer. Dette er faktorer som har vist seg å bidra positivt til økt etterlevelse (8). Internasjonale markedsundersøkelser viser at $50-70 \%$ av de spurte ville foretrekke en smeltetablett fremfor en vanlig tablett eller en flytende formulering dersom de kunne velge (9).

En vesentlig fordel med smeltetabletter er at de kan tas uten ekstra tilførsel av væske, noe som gjør dem anvendelige i situasjoner der man ikke har vann tilgjengelig $(4,5,8$, 9). De kan også inntas i liggende stilling.

Mange virkestoffer smaker bittert, og det er behov for å maskere smaken som et ledd $\mathrm{i}$ tablettfremstillingen. Smeltetabletter er nøye designet med tanke på hvordan de vil oppleves i munnen, både når det gjelder smak og tekstur $(4,5,8,9)$, og de smaker derfor ofte godt.

Smeltetabletter kan ha rask farmakologisk effekt fordi virkestoffet absorberes allerede over munnslimhinnen. Dette er velkjent fra sublingvale nitroglyserintabletter til bruk ved angina pectoris og utnyttes også ved behandling av sterke smerter og migrene (tab 1). Smeltetabletter er eneste orale administrasjonsform for buprenorfin, fentanyl og desmopressin på det norske markedet (1).

Det er publisert flere studier som demonstrerer bioekvivalens mellom smeltetabletter og vanlige tabletter av samme styrke (10-12). To doseringsformer anses som bioekvivalente hvis de etter administrasjon av samme molare dose er like med henblikk på effekt og sikkerhet. Det er vanlig å ta utgangspunkt i samme dosering for smeltetabletter og vanlige tabletter, men det finnes eksempler hvor biotilgjengeligheten er høyere fra smeltetabletter enn fra de vanlige (13). Dette gjelder spesielt virkestoffer som har en høy førstepassasjemetabolisme i tarmvegg og lever. For disse legemidlene kan og bør dosen trolig reduseres hvis man ønsker å gå over fra tabletter til smeltetabletter.

I litteraturen spekuleres det på også i om endringer i doseringsform kan være positivt på andre måter. Det er for eksempel rapportert om flere tilfeller av redusert medikament-

\section{Hovedbudskap}

- Smeltetabletter løser seg raskt opp i munnen uten tilførsel av ekstra væske

- De er velegnede produkter for pasientgrupper som har problemer med eller vegring mot å svelge tabletter

- Smeltetabletter kan gi økt biotilgjengelighet og/eller rask farmakologisk effekt sammenliknet med vanlige tabletter

- Bioekvivalens for et virkestoff må alltid vurderes ved overgang fra vanlige tabletter til smeltetabletter 
indusert vektøkning ved bruk av olanzapin i form av smeltetabletter sammenliknet med vanlige tabletter (14). En gjennomgang av rapporterte kliniske observasjoner indikerte også vektreduksjon ved overgang fra vanlige tabletter til smeltetabletter (14).

Produksjon av smeltetabletter kan skje ved hjelp av kjente teknikker og ved bruk av vanlig fremstillingsutstyr $(4,5,8,9)$. Prismessig ser det ikke ut til å være vesentlige forskjeller mellom vanlige tabletter og smeltetabletter ved sammenlikning av samme styrke og pakningsstørrelse for produktene på det norske markedet (tab 1).

\section{Utfordringer}

Rent teknisk kan smeltetabletter fremstilles ved hjelp av flere ulike teknologier - frysetørking, komprimering og ulike typer smelteteknologi. Produktenes egenskaper vil kunne variere noe avhengig av hvilken teknologi som er benyttet og hvilke virkestoffer som inngår $(4,5,8,9)$. Det betyr at det er umulig å gi universelle råd når det gjelder bytte fra vanlige tabletter til smeltetabletter. Det er alltid nødvendig å sjekke preparatomtalen (SPC) for det aktuelle preparatet ved et eventuelt bytte.

Smaksmaskering er en av de viktigste produksjonstekniske utfordringene, ettersom mange legemidler smaker bittert. Når smeltetabletten løses i munnen, vil virkestoffet frigjøres, løse seg i spyttet og komme i kontakt med smaksløkene. En bitter eller dårlig smak vil kunne gi dårligere etterlevelse (5). En utilsiktet bieffekt av smaksforbedringene kan være at produktet blir oppfattet som «sukkertøy» og dermed representere en fare for overforbruk. Det er ekstra viktig å være påpasselig med å oppbevare disse medikamentene utilgjengelig for barn.

Smaksmaskering vil ofte påvirke størrelsen på tabletten. Jo mer materiale som inngår (virkestoff + hjelpestoffer), desto større blir tablettene, og dette øker risikoen for å få følelsen av å ha sand i munnen. Dette er en utfordring, spesielt når det gjelder virkestoffer som gis i høy dose.

De fleste smeltetabletter er, som en konsekvens av hjelpestoffer og/eller produksjonsteknikker, følsomme for fukt (høy luftfuktighet). Smeltetabletter krever derfor ofte spesialpakninger som beskytter mot fukt.

Mekanisk styrke kan være en utfordring, spesielt for de smeltetablettene som er fremstilt ved frysetørking. Disse er i utgangspunktet meget skjøre og må tas forsiktig ut av de spesiallagede blisterpakningene for ikke å bli ødelagt.

Ettersom spytt er viktig for at smeltetablettene skal løses i munnen, er ikke pasienter som tar antikolinerge legemidler, har Sjögrens syndrom eller er plaget med munntørrhet av andre årsaker de beste kandidatene for å bruke smeltetabletter. Én løsning kan være å dispergere smeltetabletten i litt vann før bruk.

Det er grunn til å anta at inntak av mange
Tabell 1 Oversikt over smeltetabletter på det norske markedet (1)

\begin{tabular}{ll}
\hline Legemiddel/sykdom & Generisk navn \\
\hline Allergenekstrakt & Phleum pratense 75000 SQ-T \\
\hline Analgetikum (opioid) & $\begin{array}{l}\text { Buprenorfin } \\
\text { Fentanyl }\end{array}$ \\
\hline Analgetikum/antipyretikum & Paracetamol \\
\hline Angina pectoris/hjertesvikt & Isosorbid-trinitrat \\
\hline Antidepressivum & Mirtazapin \\
\hline Antidiuretikum & Desmopressin \\
\hline Antiemetikum & Ondansetron \\
\hline Antihistamin & Desloratadin \\
\hline Antipsykotikum & Aripiprazol \\
& Olanzapin \\
\hline Migrenemiddel & Risperidon \\
\hline Substitusjonsbehandling ved nikotinavhengighet & Rizatriptan \\
\hline Substitusjonsbehandling ved opiatavhengighet & Zolmitriptan \\
\hline Syrepumpehemmer & Bikotin \\
\hline
\end{tabular}

legemidler samtidig i form av smeltetabletter vil være en utfordring med tanke på mengde spytt tilgjengelig. For å unngå direkte interaksjon mellom ulike legemidler bør smeltetablettene tas separat, eventuelt dispergeres hver for seg i vann før bruk.

For virkestoffer hvor man ønsker en kontrollert eller forsinket frigivelse, egner ikke smeltetabletter seg, da de oppløses raskt.

\section{Konklusjon}

Smeltetabletter er brukervennlige fordi de løser seg raskt i spyttet i munnen, uten tilførsel av ekstra væske, og danner en flytende suspensjon som er lett å svelge. De er nyttige for å bedre behandlingen til pasienter som har problemer med eller vegring mot å svelge tabletter. Internasjonale markedsunders $\varnothing$ kelser tyder på at store deler av befolkningen kan være interessert i smeltetablettene pga den gode smaken og fordi de er praktiske og lette å ta. Smeltetabletter kan gi økt biotilgjengelighet og/eller rask farmakologisk effekt sammenliknet med vanlige tabletter. Bioekvivalens for et virkestoff må alltid vurderes ved overgang fra vanlige tabletter til smeltetabletter. De viktigste produksjonstekniske utfordringene for denne doseringsformen er behovet for smaksmaskering, følsomhet mot fukt under produksjon og lagring samt lav mekanisk styrke i forbindelse med håndtering

\section{Ingunn Tho (f. 1970)}

er cand.pharm., dr.scient. i galenisk farmasi (legemiddelteknologi og biofarmasi) med spesialisering innen faste legemiddelformer og professor ved Institutt for farmasi, Universitetet i Troms $\varnothing$.

Ingen oppgitte interessekonflikter.

\section{Litteratur}

1. Felleskatalogen 2011 www.felleskatalogen.no (24.7.2011).

2. Norsk legemiddelstandard 2011 www.legemiddelverket.no (24.7.2011).

3. European Pharmacopeia. 7. utg. http://online.pheur.org/ (24.7.2011).

4. Sastry SV, Nyshadham JR, Fix JA. Recent technological advances in oral drug delivery - a review. Pharm Sci Technol Today 2000; 3: 138-45.

5. Douroumis D. Orally disintegrating dosage forms and taste-masking technologies; 2010. Expert Opin Drug Deliv 2011; 8: 665-75

6. Thomson SA, Tuleu C, Wong IC et al. Minitablets: new modality to deliver medicines to preschoolaged children. Pediatrics 2009: 123: e235-8.

7. Stoltenberg I, Breitkreutz J. Orally disintegrating mini-tablets (ODMTs) - a novel solid oral dosage form for paediatric use. Eur J Pharm Biopharm 2011; 78: 462-9.

8. Navarro V. Improving medication compliance in patients with depression: use of orodispersible tablets. Adv Ther 2010; 27: 785-95.

9. Hirani JJ, Rathod DA, Vadalia KR. Orally disintegrating tablets: a review. Trop J Pharm Res 2009; 8: $161-72$

10. Davidson N, Rapoport B, Erikstein B et al. Comparison of an orally disintegrating ondansetron tablet with the conventional ondansetron tablet for cyclophosphamide-induced emesis in cancer patients: a multicenter, double-masked study. Clin Ther 1999; 21: 492-502

11. Fass R, Pieniaszek HJ, Thompson JR. Pharmacokinetic comparison of orally-disintegrating metoclopramide with conventional metoclopramide tablet formulation in healthy volunteers. Aliment Pharmacol Ther 2009; 30: 301-6.

12. Loder EW, Dowson AJ, Spierings EL. Part II: clinical efficacy and tolerability of zolmitriptan orally disintegrating tablet in the acute treatment of migraine. Curr Med Res Opin 2005; 21 (suppl 3): S8-12.

13. Seager H. Drug-delivery products and the Zydis fast-dissolving dosage form. J Pharm Pharmaco 1998; 50: 375-82.

14. Karagianis J, Hoffmann VP, Arranz B et al. Orally disintegrating olanzapine and potential differences in treatment-emergent weight gain. Hum Psychopharmacol 2008; 23: 275-81. 